\title{
INCOME SMOOTHING PRACTICES AND CONSERVATISM IN BRAZILIAN CREDIT UNIONS
}

\author{
PRÁTICAS DE INCOME SMOOTHING E CONSERVADORISMO EM COOPERATIVAS DE CRÉDITO \\ BRASILEIRAS
}

\section{Ramon Rodrigues dos Santos}

ramon.rodrigues@ufpe.br

Programa de Pós-Graduação em Administração/Universidade Federal de Pernambuco - Recife/PE, Brasil ORCID: https://orcid.org/0000-0002-3413-3333

\section{Joséte Florencio dos Santos \\ jfs@,ufpe.br \\ Programa de Pós-Graduação em Administração/Universidade Federal de Pernambuco - Recife/PE, Brasil ORCID: https://orcid.org/0000-0002-5366-2548}

\begin{abstract}
This paper analyzes the relationship between income smoothing practices in the conservatism of Brazilian credit unions, from the of Eckel (1981) and Ball and Shivakumar (2005) models between the years 2012 to 2018, in a total of 5,717 observations. The results highlighted a higher level of conservatism on the part of non-smoother credit unions, demonstrating that by smoothing the remains of the cooperative, managers seek to be less conservative when advancing possible losses, reversing lower results in subsequent periods, confirming the research hypothesis.
\end{abstract}

Keywords: Income Smoothing. Conservadorism. Credit Unions.

\section{Resumo}

Este trabalho analisa a relação das práticas de income smoothing no conservadorismo das cooperativas de crédito brasileiras, a partir dos modelos de Eckel (1981) e Ball e Shivakumar (2005) entre os anos de 2012 a 2018, em um total de 5.717 observações. Os resultados destacaram um maior nível de conservadorismo por parte das cooperativas de crédito non-smoothers, demonstrando que ao suavizar as sobras da cooperativa, os gestores buscam ser menos conservadores ao adiantar possíveis perdas, revertendo menores resultados em períodos subsequentes, confirmando a hipótese de pesquisa.

Palavras-chave: Income Smoothing. Conservadorismo. Cooperativas de Crédito. 


\section{Introduction}

The form of organization of a company is considered a factor that can affect the quality of the information reported (Ball \& Shivakumar, 2005). In the case of credit unions, the shareholding structure is very dispersed and generally has millions of members, all with the same power (the idea of "one member, one vote"). The widely dispersed association, regardless of the shareholding that each member actually holds, tends to provide more autonomy to management and, therefore, increases the importance and complexity of monitoring these entities (John, De Masi, \& Paci, 2016).

Moreover, these organizations tend to have a management aimed at maximizing value, growth and maintaining their market position, although such maximization does not ensure their survival (Carvalho, Diaz, Bialoskorski Neto \& Kalatzis, 2015). Thus, the possibility of maximizing the utility function of managers through decisions that affect the gains creates incentives for strategies to be used in order to "hide" gains in more profitable periods and the presenting in less profitable times.

In order to reduce the volatility of net income and taking into account the aforementioned motivations, there are several mechanisms for its management, among which it is possible to highlight the income smoothing, that seeks, in the context of credit unions, to preserve the distribution of leftovers to the cooperates or to change the perceptions of risk of the company by the market, being seen, consequently, with more confidence by investors (Bressan, Souza \& Bressan, 2017). In an initial discussion, this fact is justified by Hepworth (1953), noting that the owners and creditors of a company feel more confident with the corporate administration that is able to report stable profits, than if there is a considerable Fluctuation of reported profits.

In addition, Lara, Osma and Penalva (2016) argue that conservatism improves the efficiency of investments. Thus, they believe that conservatism solves the debt-equity conflict, facilitating the firm's access to debt financing and limiting underinvestments, that is, projects with negative NPV (Net Present Value), allowing the financing of prudent investments which could not be pursued otherwise.

Among the possible decisions available to managers, there is the possibility that these are conservative, recognizing in advance the losses (or "bad" news) to the detriment of profits and assets ( the "good" news), that is, underevaluating the assets and overevaluating the liabilities (Zeghal \& Lahmar, 2018). Osma, Mora and Porcuna-Enguix (2019) emphasize that the reduction of optimism in the disclosed result is, theoretically, a characteristic of accounting conservatism, and at the same time, a consequence practices of income smoothing, since conservative companies have a lower level of results smoothing. In this way, it is understood that these two practices influence the same context, even from different concepts.

In this aspect, this article aims, in a first effort, to analyze the relationship of income smoothing practices in the conservatism of Brazilian singular credit unions, assuming that the profits reported by the credit cooperatives are, in fact, surplus or "leftovers" determined by the result of products and services at the end of each annual cycle. This dimension directly influences the growth of these institutions, which have specific characteristics, and in particular those related to the financial intermediation policy and a single set of provision of rights of Participation, since customers, at the same time, are associates and owners (Rixon \& Lightstone, 2016; Jansen, Maehler \& Wegner, 2018).

Credit unions have been an alternative to new business and, therefore, are seen as a recent research object explored in multidisciplinary perspectives, from the perspective of its efficiency, its growth, its performance, of good practices, among others, since these aspects generate positive impacts on the performance of credit unions. On the other hand, the limitations related to its functioning, regulation, accounting methodology and disclosures of its results also induce the exploration of new studies.

To achieve the research problem, this article is divided into five more sections, in addition to this introduction. The next topic deals with the theoretical framework, addressing a survey on the National 
Cooperative Credit System (SNCC), income smoothing and accounting conservatism, in addition to studies related to the themes. In the third topic, the methodological procedures, from the work of Eckel (1981) and Ball and Shivakumar (2005), the sample for this work and the Panel diagnostic tests. Soon after, the results and respective analyses, the final considerations and the references.

\section{Income Smoothing and Accounting Conservatism}

The practice of conservatism can be understood as asymmetric recognition of good and bad news, in which published profits tend to reflect economic losses more timely than economic gains (Basu, 1997). If this asymmetric recognition comes from a set of practices adopted by managers to obtain desirable accounting results, it is then possible to configure the management or smoothing of results (Rezende \& Nakao, 2012).

In this respect, income smoothing, also called "smoothing results", also called "result smoothing", is intended to provide a more stable view of future results flows, which contributes to the Investors have a reduced view of systematic risk, as well as constant growth over time (Hepworth, 1953). In general, works such as those of Eckel (1981) and Lambert (1984) provide classifications for the different types of income smoothing. For the first, the smoothing ofthes result occurs in two ways: naturally or intentionally. According to Lambert (1984), income smoothing can be classified as discretionary or non-discretionary. Following these studies, preliminary approaches to the management of accounting results depart, in Brazil, with more emphasis on the works of Martinez (2001, 2006, 2013).

The practice of smoothing results, as mentioned, reduces managers' ability to reflect the economic reality of the company. Regardless of what the intention of managers to do so, it should be borne in mind that there are other ways of these to exercise this arbitrary power, as through conservatism, since companies can be more or less conservative in their accounting policies, thus affecting the result (Martinez, 2001).

According to Basu (1997), the practice of conservatism can be understood as asymmetric recognition of good and bad news, and consequently it is hoped that the published profits reflect economic losses more timely than economic gains. Watts (2003) treats conservatism from three perspectives, namely: the first, related to the tendency of greater accuracy to recognize gains to the detriment of losses, as a way to draw more reliable contractual metrics; the second, which considers conservatism as the maximum of "postponing revenues and anticipating expenses"; and, the third, from the undervaluation of shareholders' equity through the reduction of the accounting profit derived from the delay in the recognition of revenues.

Accounting conservatism can be classified into two types: conditional and unconditional (Ball \& Shivakumar, 2005). Unconditional conservatism is related to the choice of lower value for assets and revenues and of higher value for liabilities and expenses, and is inherent in accounting principles and norms, so that it does not depend on a management action, which in this respect may be related to the non-discretionary component of income smoothing. Conditional conservatism is linked to asymmetry in the recognition of good news (gains) and bad news (losses), which depends on a management action to recognize, in advance or not, the losses, which, in this context, is related to the artificial (discretionary, arbitrary) component of smoothing.

This article aims to apply conditional conservatism, which can be defined as the accounting bias in reporting low values for the independent equity of signs of probable economic losses, which may be Conditional on the practice of income smoothing by Brazilian credit unions. According to Ball and Shivakumar (2005), managers possessed a historical tendency to anticipate losses, but do not perform the same procedure for profits. However, in the case of credit unions, different from companies listed in stock or with closed shareholding, a trade-off relationship with the smoothing of results is understood, since a greater loss report and a result in a direct environment of uncertainty between the cooperative 
and its cooperates, which at the same time are clients and members of this entity. In this context, the research hypothesis is:

\section{H1: The leftovers reported in non-smoothers Credit Cooperatives are more conservative than those disclosed by smoothers Credit Unions.}

Thus, this hypothesis assumes that non-smoothers credit cooperatives would more appropriately recognize their economic losses than smoothers, since they would not exist, for these, factors Motivations for the smoothing of the leftovers reported in their demonstrations. It is worth remembering that the relations between income smoothing and conditional conservatism are far from obvious or mechanical, since this relationship is given to the position of profits in a given period and that the distribution of Profits would be postponed over time, remaining unchanged (Firnanti, 2019; Osma, Mora \& PorcunaEnguix, 2019).

Subsequently, it is possible to identify studies exploring the scientific production on income smoothing and the attributes of the accounting quality applied to banking institutions and credit unions, in segments, groupings and Different periods. It is noteworthy that there is still a gap in the literature that analyzes the relationship between the practices of Income smoothing and conservatism in credit cooperatives, since the national and, including the International ones, analyze, in isolation, the behavior of one of these attributes.

\section{Related Studies}

The first study on income smoothing in Brazilian credit unions was carried out by Maia, Bressan and Lamounier (2013) when working with cooperatives Associated with the Sicoob cooperative system in the period between the first quarter of 2001 to the third quarter of 2011. The authors identified that there are credit cooperatives that practice income smoothing in order to contain large fluctuations in their results, since a great volatility It may indicate a situation of economic fragility and risk, from the cooperative to its shareholders. Subsequently, Bressan, Bressan and Silva Júnior (2015) corroborate the afore mentioned results when analyzing income smoothing in the singular cooperatives linked to the Sicredi cooperative system, between 2000 and 2010.

In sequence, the study by Bressan, Bressan and Silva Júnior (2016) investigated the practice of results management in the income smoothing modality in Credit unions in Brazil affiliated with the Sicredi Cooperative credit system. The sample consisted of 149 cooperatives, with semiannual data referring to the period from 2001 to 2011, totaling 2,300 observations. The results indicate the use of accounting discretion to soften the results, that is, the statistically positive and significant result allows inferring that the greater the non-discretionary result, the greater tends to be the net expense with provisions for credit operations. This result corroborates the perception of analysts of the Central Bank of Brazil that the Brazilian financial institutions, regardless of being a bank or a credit cooperative, choose to soften the results.

Bressan, Souza and Bressan (2017) analyzed whether the credit unions affiliated with the National Confederation of Central Cooperatives Unicred manage their accounting results, in order to reduce the variability of the institution's returns and transmit a solidity signalling to the cooperates. The findings also indicated the smoothing of the results, that is, it can be inferred that the cooperatives affiliated to the Unicreds make use of the practice of results management, in the modality income smoothing.

Carvalho, Pereira and Dantas (2018) verify that the Brazilian financial institutions use the discretionary portion of the allowance for doubtful debts (PCLD) as a capital management instrument, analyzing the quarterly data of 2000 to 2015 of the 50 largest conglomerates and financial institutions acting in the National Financial System (SFN), considering two variables representative of the capital level: the Basel Index, regulatory measure of capital Requirement; and a proxy based on accounting information. The 
results of the tests revealed that there is no evidence that Brazilian banks use the discretion in the constitution of the PCLD for capital management purposes. On the other hand, they reinforced the evidence of previous national and international studies on the subject, in the sense that the institutions use this discretion in the PCLD with the purpose of managing results.

In relation to the works that highlight the attributes of the quality of accounting information, Arruda, Vieira, Paulo and Lucena (2015), assuming that the accounting measurement process of financial institutions differs substantially from the other companies, sought to analyze the levels of conservatism and persistence of the accounting results of Brazilian open and closed financial institutions in the period between 1996 and 2013. The results of the research identified that none of the types of financial institutions present timely recognition of the losses occurring during the analyzed period. In relation to the persistence of accounting results, the analyses pointed out that closed financial institutions have greater persistence in their accounting results than open institutions, resulting in greater predictability of future profits for present profits.

Subsequently, in a first effort to analyze the attributes of the quality of accounting information in credit cooperatives, the work of Diniz and Girão (2019) verified the persistence of leftovers in these institutions between 2000 and 2017, through a panel balanced between 2000 and 2017, in a total of 700 cooperatives and 12,600 observations, divided into two samples (larger and smaller cooperatives, above and below $\mathrm{R} \$ 50$ million of total assets, respectively), applying the Dechow and Schrand model (2004). The results identified that there is a persistence in the remains of the entire set of singular credit cooperatives in the period analyzed, highlighting that the larger credit cooperatives have greater persistence of the leftovers than the cooperatives of smaller credit.

Finally, Diniz (2020), among other attributes of the quality of accounting information, sought to evaluate whether the financial statements reported by the larger Brazilian singular credit unions would be more conservative than those reported by the credit unions in the period 2000-2018. To this end, the author applied the model developed by Ball and Shivakumar (2005), classifying the research sample into two groups, from the balance of their total assets in the respective periods (greater than or less than $\mathrm{R} \$ 50$ million). The results highlight that there may be timely recognition of good news that can be reversed in future periods and the presence of conservatism in the results reported in the statements of credit unions. In moreover, a difference was identified in conservative behavior among the groups analyzed, with larger cooperatives being more conservative than the smaller ones in the reported information.

\section{Methodological Procedures}

\section{$\underline{\text { Research Sample }}$}

The population of this work is composed of Brazilian, singular, central and confederational credit cooperatives, affiliated or not to existing cooperative systems, under the supervision of the Central Bank of Brazil (Brazilian Central Bank [Bacen], 2019) and operating in the country, on an annual basis, between 2012 and 2018, in a total of 7,714 observations. It is noteworthy that this research contemplated the years 2010 and 2011 for the estimation of variables with outdated calculation (t-1 and t-2) and that the initial period refers to the availability of 4016 documents (balance sheets) on the website of the Central Bank of Brazil and the full validity of the effects of Complementary Law No. 130 (Brazil, 2009) that provides on the National Cooperative Credit System, until the last complete social year.

However, assuming that all negotiations with the cooperative are in charge of the singular, and that the central and confederations have the function of operational support in the provision of services and access to the products of the financial market, it is proposed, as a research sample, only the singular cooperatives, since the examination together with the data of the central and confederations could cause bias in the results pointed out, excluding a total of 264 observations. 
Soon after a conference between the cooperatives listed on the Bacen website and those that reported their balance sheets in the respective periods, cooperatives that did not have all observations for the analyzed period were excluded, totaling 6,300 observations. The balanced panel is suitable so far, as indicators based on Eckel (1981) and Ball and Shivakumar (2005) models need to be calculated between 2012 and 2018. It is understood that, after calculation, observations can be handled individually, and may result even in an unbalanced panel.

The data proposed in the present study already disregard cooperatives in the process of incorporation, whose data were consolidated in the respective Extraordinary General Assemblies, according to Circular No. 1,273 (Bacen, 1987). Document 4016 is sent to the Central Bank until the last working day of July (referring to the period from $01 / 01$ to $06 / 30$ ) and January of the subsequent financial year (referring to the last fiscal year, i.e. $01 / 01$ to 12/31), however, for the present study, we sought to use the observations only on an annual basis, since the end of the exercises. Table 1 presents the sequence of data processing for the composition of the research sample.

Table 1

\section{Research Sample}

\begin{tabular}{|c|c|c|}
\hline$(=)$ & Initial Remarks & 7.714 \\
\hline$(-)$ & Confederations of Credit Cooperatives & 25 \\
\hline$(-)$ & Central Credit Cooperatives & 239 \\
\hline$(-)$ & Conference: Bacen Report 4016 Document & 36 \\
\hline$(=)$ & Unbalanced total observations & 7.414 \\
\hline$(-)$ & Missing remarks & 1.114 \\
\hline$(=)$ & Total observations & 6.300 \\
\hline$(-)$ & Cooperatives with Negative Shareholders' Equity (uncovered book value) & 63 \\
\hline$(=)$ & Cooperatives without Negative Shareholders' Equity & 6.237 \\
\hline$(-)$ & $\begin{array}{l}\text { Variables with errors or incomplete related to Eckel's model (1981) - no net income (leftovers or losses) } \\
\text { of the cooperative in the period } t\end{array}$ & 315 \\
\hline$(=)$ & Error-free or incomplete observations regarding Eckel's model (1981) & 5.922 \\
\hline$(-)$ & Observations in the "gray area" of the Eckel model (1981) & 165 \\
\hline$(=)$ & Valid observations & 5.757 \\
\hline$(-)$ & Observations +/- 3 standard deviations for Eckel model (1981) & 34 \\
\hline$(-)$ & Observations +/- 3 standard deviations for Ball and Shivakumar model (2005) & 6 \\
\hline \multirow{3}{*}{$(=)$} & Valid observations & 5.717 \\
\hline & Smoothers Singular Credit Unions & 3.125 \\
\hline & Non-Smoothers Singular Credit Unions & 2.592 \\
\hline
\end{tabular}

According to Table 1, the sample for this article consisted of a total of 5,717 observations, of which 3,125 (54.6\%) correspond to those credit unions that, from Eckel's model (1981) softened their results (smoothers) and 2,592 (45.4\%) those that have not softened (non-smoothers). This sample reinforces the thesis that Brazilian credit cooperatives perform income smoothing, as already demonstrated in previous studies (Maia, Bressan and Lamounier, 2013; Bressan, Bressan \& Silva Júnior, 2016; Bressan, Souza \& Bressan, 2017; Carvalho, Pereira \& Dantas, 2018).

\section{Proposed Models and Panel Diagnostic Tests}

First, this work proposes the operationalization of credit unions in smoothers and non-smoothers, from the methodology proposed by Eckel (1981), adapted for credit unions, and, in sequence, for the measurement of the level of conservatism, adapting the model proposed by Ball and Shivakumar (2005) for these same institutions.

The Eckel Smoothing Index (1981) seeks to identify whether a company artificially softens its results or not, assuming that revenues and costs are linear overtime, growing or decreasing by going in the same 
proportion. Therefore, when this relationship does not occur, there may be some interference from executives to smooth the results. The logic in using this model is so that there is the possibility of objectively dividing the sample into two groups of firms: the smoothing (smoothers) and non-smoothers.

To observe this relationship between profit and revenue, the percentage coefficients of profit and sales revenue are used. It is noteworthy that in the case of financial institutions, revenues arising from financial intermediation, provision of banking services and bank tariffs were considered to determine the variation in sales; net income was due to the difference between income tax and profit sharing by employees of the result before taxation (Santos, Rodrigues, Anjos \& Tavares, 2019), according to Equation 1.

$$
\Delta \% \text { Net Income } \leq \Delta \% \text { Operating Income }=\text { "Smoothing" }
$$

In what: $\Delta \%$ Net Income $=\left(\right.$ Net Income $_{t}-$ Net Income $\left._{t-1}\right) /$ Net Income $_{t-1}$ e $\Delta \%$ Operating Income $=$ (Operating Income $t_{t}-$ Operating Income $_{t-1}$ )/Operating Income ${ }_{t-1}$.

From this data, the smoothing of results is calculated, expressed by the Eckel Smoothing Index (IE) formula, according to Equation 2.

$$
\mathrm{IE}=\frac{\Delta \% \text { Net Income }}{\Delta \% \text { Operating Income }}
$$

Following the procedure of Martinez and Castro (2011) establishes a gap between 0.9 and 1.1, as "gray area", where it is not possible to classify firms in smoothers and non-smoothers. This procedure allows the classification of firms objectively, reducing the risk of bias on the part of the researcher. Observations within this range can be excluded or studied a posteriori, being considered as neutral (neutral) institutions. To view this range, the following formula displays the gray area:

$$
0,9 \leq|\mathrm{IE}| \leq 1,1
$$

This means that if the index obtained is less than 0.9 , the credit union practices income smoothing and, if the index obtained is greater than 1.1, the credit union did not practice income smoothing. From this perspective, it proposes a recording of the variable IE, transforming it into a binary variable (dummy), in which it is attributed 1 (one) to companies that presented coefficient less than 0.9 and 0 (zero), for companies that presented this coefficient above 1.1.

In sequence, for the measurement of the level of conservatism of Brazilian singular credit cooperatives, adapting the conditional model proposed by Ball and Shivakumar (2005) for these institutions, according to Equation 4.

$$
\Delta \mathrm{NI}_{\mathrm{it}}=\beta_{0}+\beta_{1} \mathrm{D} \Delta \mathrm{NI}_{\mathrm{it}-1}+\beta_{2} \Delta \mathrm{NI}_{\mathrm{it}-1}+\beta_{3} \Delta \mathrm{NI}_{\mathrm{it}-1} * \mathrm{D} \Delta \mathrm{NI}_{\mathrm{it}-1}
$$

In what: $\Delta \mathrm{NI}_{\mathrm{it}}$ : variation in the net income of the cooperative $\mathrm{i}$ of the year $\mathrm{t}-1$ to the year $\mathrm{t}$; $\mathrm{D} \Delta \mathrm{NI} \mathrm{it}_{\mathrm{it}}$ : variable that indicates whether there was a negative variation in the net income of the cooperative of the year $\mathrm{t}-1$ for the year $\mathrm{t}$; $\left(\Delta \mathrm{NI}_{\mathrm{it}}\right.$ ), assuming 1 (one) if $\Delta \mathrm{NI}_{\mathrm{it}}<0$, and 0 (zero) otherwise; $\mathrm{NI}_{\mathrm{it}-1}$ : variation in the net leftovers of the cooperative $i$ of the year $\mathrm{t}-2$ to the year $\mathrm{t}-1$; and $\varepsilon_{\mathrm{it}}$ : robust standard error, by the HAC matrix of Newey-West.

The untimely recognition of economic gains, deflating the incorporation into the result until these increases in cash flow are realized, causes earnings to be recognized as "persistent" positive components of accounting profit, which do not tend to be reversed. Therefore, the implication of the original model of conditional conservatism is that $\beta_{2}=0$, whereas timely recognition of losses is measured by the coefficient of $\beta_{3}$. As an end, the cooperatives that present conditional conservatism in their reports are expected to be recognized more in due course than the gains, as a transitional decrease of these. Therefore, the implication is that $\beta_{3}<0$ e de que $\beta_{2}+\beta_{3}<0$ (Ball \& Shivakumar, 2005). 
To analyze the relationship between income smoothing practices and conditional conservatism of credit unions, a panel data regression was used, with the support of the Gretl Statistical Software. The main advantage of the use of panel data models is related to the combination of the time series with crosssectional observations, and consequently, a greater control of the heterogeneity of observations, the use of a greater amount of information, besides mitigating the impact of omitted variables on regression results (Fávero \& Belfiore, 2017).

Preliminary, validation tests were intended to analyze the application of the model estimated by Ordinary Squares or by fixed or random panel analysis. For the analysis between the estimation by OLS and the modeling of data in panel by fixed effects, the Chow Test was performed, with the null hypothesis that the intercepts of the dummies have the same parameters. The Chow Test rejected the null hypothesis of structural stability, which indicated the use of data modeling in a fixed effects panel ( $p$-value: 0.000). The panel data regression model with fixed effects, since it considers the existence of individual effects that represent heterogeneities between individuals and capture their invariant differences in time, that is, differences in interceptions, and not in inclinations (Gujarati \& Porter, 2011; Fávero \& Belfiore, 2017).

In sequence, the Breusch-Pagan Test was applied, based on the Lagrange multiplier (LM), in order to analyze whether the OLS model is more relevant than random effects panel data modeling. The results highlighted that the p-value resulting from the test (0.164) invalidates the hypothesis of the existence of possible random effects in the sample. The logic behind the models estimated by random effects is that, unlike the models estimated by fixed effects, the variation between individuals is considered random and not correlated with the explanatory variables (Fávero \& Belfiore, 2017).

Finally, the authors suggest the Hausman Test to evaluate, among the panel data models with fixed and random effects, which is most appropriate, starting from the null hypothesis that random effects modeling estimates are efficient and consistent. Consequently, if the hypothesis is rejected, fixed-effect estimation should be used. In this respect, the p-value (0.000) allowed rejecting the null hypothesis, indicating the use of the model by fixed effects.

In addition, the inclusion of OLS estimation in the analysis of panels allows identifying the possible existence of multicollinearity among estimators, assuming that, in the variance inflation test (IVF), values closer to 1.0 highlight that the set of variables is not correlated, and that above 10.0 (in more conservative criteria, above 5.0 (Gujarati \& Porter, 2011), which did not occur in any of the variables of this study. Subsequently, the results of this article present a descriptive statistic of the variables, in addition to the analysis of the correlation between them and, finally, the application of Equation 4, proposed for this work, based on the models of conservatism of Ball and Shivakumar (2005).

\section{Results}

Table 2 presents the composition of panels $\mathrm{A}$ and $\mathrm{B}$, with descriptive statistics of credit cooperatives smoothers and non-smoothers. In a preliminary way, it is observed that the standard deviation of the Eckel Index (IE), despite the data treatment, was still high, however, this fact does not cause impacts on the results, considering that it was used only for the grouping between cooperatives that smoothed their results during the analysis period.

It can be noted, according to the table above, that the variation in net leftovers from year $\mathrm{t}-1$ to year $\mathrm{t}$ in smoother cooperatives, is higher, with a difference of $5.1 \%$, in the mean, and $2.6 \%$, in the median, when compared with non-smoothers. The same behavior remains in the variation in net leftovers from $\mathrm{t}-2$ year to year $\mathrm{t}-1$, however, with a smaller difference of $0.5 \%$ in the mean, and $0.3 \%$ of the median. This greater variation among the first can also be justified by the extreme values found in the smoothers credit unions, with emphasis on the maximum value of this group (151.8\%), in addition to the discretionary component of cooperatives that soften results, which would allow for greater manipulation in these variations. 
Table 2

\section{Descriptive Statistics}

\begin{tabular}{|c|c|c|c|c|c|}
\hline \multicolumn{6}{|c|}{ Smoothers $(\mathrm{n}=3.125)$} \\
\hline Variables & Mean & Median & Minimum & Maximum & Standard Deviation \\
\hline IE & $-10,74$ & $-1,368$ & $-599,9$ & 0,899 & 41,54 \\
\hline$\Delta \mathrm{NI}_{\mathrm{it}}$ & 0,196 & 0,148 & $-0,815$ & 1,518 & 0,459 \\
\hline $\mathrm{NI}_{\mathrm{it}-1}$ & 0,198 & 0,165 & $-0,815$ & 3,935 & 0,291 \\
\hline$\Delta \mathrm{NI}_{\mathrm{it}-1} * \mathrm{D} \Delta \mathrm{NI}_{\mathrm{it}-1}$ & 0,04 & 0,000 & $-0,791$ & 2,031 & 0,158 \\
\hline \multicolumn{6}{|c|}{ Non-Smoothers $(\mathrm{n}=2.592)$} \\
\hline Variables & Mean & Median & Minimum & Maximum & Standard Deviation \\
\hline $\mathrm{IE}$ & 24,59 & 4,422 & 1,101 & 1173 & 86,39 \\
\hline$\Delta \mathrm{NI}_{\mathrm{it}}$ & 0,145 & 0,122 & $-0,753$ & 1,287 & 0,22 \\
\hline $\mathrm{NI}_{\text {it-1 }}$ & 0,193 & 0,168 & $-0,753$ & 3,643 & 0,262 \\
\hline$\Delta \mathrm{NI}_{\mathrm{it}-1} * \mathrm{D} \Delta \mathrm{NI}_{\mathrm{it}-1}$ & 0,0333 & 0,000 & $-0,555$ & 3,643 & 0,167 \\
\hline
\end{tabular}

Note. Caption: $\mathrm{n}$ : number of observations; IE: Eckel Index (1981); $\Delta \mathrm{NI}_{\mathrm{it}}$ : variation in the net income of the cooperative $\mathrm{i}$ of the year $\mathrm{t}-1$ to the year $\mathrm{t}$; $\mathrm{D} \Delta \mathrm{NI}_{\mathrm{it}-1}$ : variable that indicates whether there was a negative variation in the net income of the cooperative of the year $\mathrm{t}-1$ for the year $\mathrm{t} ;\left(\Delta \mathrm{NI}_{\mathrm{it}}\right)$, assuming 1 (one) if $\Delta \mathrm{NI}_{\mathrm{it}}<0$, and 0 (zero) otherwise; and $\mathrm{NI}_{\mathrm{it}-1}$ : variation in the net leftovers of the cooperative i of the year $\mathrm{t}-2$ to the year $\mathrm{t}-1$.

In sequence, Table 3 presents the results related to the analysis of conservatism in credit unions smoothers and non-smoothers, according to Equation 4.

Tabela 3

Search Results

\begin{tabular}{|c|c|c|c|c|}
\hline \multirow[t]{2}{*}{ Variables } & \multicolumn{2}{|c|}{ Smoothers } & \multicolumn{2}{|c|}{ Non-Smoothers } \\
\hline & Coeficiente & Erro-Padrão & Coeficiente & Erro-Padrão \\
\hline Constant & $0,252^{* * *}$ & 0,002 & $0,196 * * *$ & 0,007 \\
\hline $\mathrm{D} \Delta \mathrm{NI}_{\mathrm{it}-1}$ & $-0,344 * * *$ & 0,004 & $0,267 * * *$ & 0,009 \\
\hline$\Delta \mathrm{NI}_{\mathrm{it}-1}$ & $0,098^{* * *}$ & 0,008 & $0,074 * * *$ & 0,035 \\
\hline$\Delta \mathrm{NI}_{\mathrm{it}-1} * \mathrm{D} \Delta \mathrm{NI}_{\mathrm{it}-1}$ & $-0,166^{* *}$ & 0,018 & $-0,222^{* * *}$ & 0,045 \\
\hline R-square & \multicolumn{2}{|c|}{0,751} & \multicolumn{2}{|c|}{0,621} \\
\hline R-square set & \multicolumn{2}{|c|}{0,750} & \multicolumn{2}{|c|}{0,591} \\
\hline F (prob; p-value) & \multicolumn{2}{|c|}{$257,437(0,000)$} & \multicolumn{2}{|c|}{$461,729(0,000)$} \\
\hline Observations (n) & \multicolumn{2}{|c|}{3.125} & \multicolumn{2}{|c|}{2.592} \\
\hline
\end{tabular}

Note. Caption: $\Delta \mathrm{NI}_{\mathrm{it}}$ : variation in the net income of the cooperative $\mathrm{i}$ of the year $\mathrm{t}-1$ to the year $\mathrm{t}$; $\mathrm{D} \Delta \mathrm{NI}_{\mathrm{it}-1}$ : variable that indicates whether there was a negative variation in the net income of the cooperative of the year $\mathrm{t}-1$ for the year $\mathrm{t}$; $\left(\Delta \mathrm{NI} \mathrm{I}_{\mathrm{it}}\right)$, assuming 1 (one) if $\Delta \mathrm{NI}_{\mathrm{it}}<0$, and 0 (zero) otherwise; and $\mathrm{NI}_{\mathrm{it}-1}$ : variation in the net leftovers of the cooperative $\mathrm{i}$ of the year $\mathrm{t}-2$ to the year t-1. Standard error in parentheses. Significance: ***: $0.01 \%, * *: 0.05 *$ : 0.1.

According to Table 3, the results indicate timely recognition of good news from smoothers and nonsmoothers credit cooperatives, reverted in subsequent periods $\left(\beta_{2}\right)$. As a result, the results highlight that the possibility of maximizing the usefulness of managers through decisions that affect the gains of credit unions would create incentives for these to "hide" gains in more profitable periods, presenting them in less profitable times and their reversals in subsequent years. The variable $\Delta \mathrm{NI}_{\mathrm{it}-1} * \mathrm{D} \Delta \mathrm{NI}_{\mathrm{it}-1}\left(\beta_{3}\right)$ indicates conservative behavior in both classifications, which would also entail credit unions, in general, timely recognition of losses, although more significantly in non-smoother credit cooperatives, which corroborates, in general, the findings of Diniz (2020).

It is worth remembering that according to Lambert (1984), income smoothing can be classified as discretionary or non-discretionary. The management of the type "non-discretionary" is one that manifests itself in the occasions of decision-making on investments or by requirement of the regulatory body, and, 
in fact, in the variability of the results obtained. The technique by the type "discretionary", however, is linked exclusively to the accounting decisions made by the company without any corresponding real action, through the excess provision in relation to the mandatory minimum.

The National Cooperative Credit System Panorama highlights that the portfolio of natural credit cooperatives remained classified mostly at risk levels A and B. However, it observes, in the period between 2014 and 2017, a slight deterioration in the risk rating of the portfolio, with a drop in the proportion of operations at risk level $\mathrm{A}$ and concomitant increase in risk levels $\mathrm{B}, \mathrm{C}$ and $\mathrm{D}$, which increases the PCLD and by consequently, the economic losses of these institutions; in 2017, the PCLD coverage index in relation to the total classified portfolio (from A to $\mathrm{H}$ ) was 1.72 (Bacen, 2018). Considered the above, credit unions can reverse their gains or losses not necessarily by the conservative component, but by the regulator's requirement to provision and reverse in the subsequent period the provisions for credit with dubious liquidation, the PCLD, guided by Resolution No. 2,682 (Brazil, 1999).

Finally, the sum of the $\beta_{2}$ and $\beta_{3}$ coefficients for the credit cooperatives smoothers and non-smoothers are respectively -0.068 and -0.148 . As in both cases these sums are less than zero $\left(\beta_{2}+\beta_{3}<0\right)$, it was found that the figures present empirical evidence of timely recognition of losses, which were reversed in the following periods. In a comparison between the sum of the coefficients $\beta_{2}$ and $\beta_{3}$ of the model presented in Equation 4, it was found that non-smoothers credit cooperatives have a greater reversal of negative results in relation to credit unions smoothers, confirming the hypothesis proposed in this research.

From this singular characteristic of this institutional type, two other pressures are added to the cooperative society - political and social pressure - in addition to economic pressure. The political pressure is related to the internal dispute for power, given the need for the cooperative to have a democratic and legitimate representation before the community of members. Social pressure, on the other hand, lies in remaining useful and legitimate socially - as a doctrine in which cooperation leads to mutual benefits - between associates and their respective families (Arruda, 2014).

With this, the disclosure of negative results or with a great variability can denote a risk situation for credit unions, referring to the cooperative members an idea of inefficiency or even economic and financial insecurity of the entity (Maia et al., 2013). For this reason, it is understood that credit unions could be motivated to manage their results, not reporting losses (the "bad news", sometimes applying arbitrary criteria to hide this deficit situation, sometimes recognizing the leftovers over future periods, as cash flows are realized. Thus, the discretionary power of the manager when practicing the smoothing of results would be associated with a lower level of conservatism, thus influencing the leftovers reported by smothers credit unions.

In this context, it is important to analyze how much conditional conservatism practices in these institutions affect the outcome of these entities, since when the balance of estimated losses with dubious settlement credits is insufficient to absorb their losses, greater recognition of these credit operations causes financial institutions to face possible liquidity problems, forcing them to reduce their slack and their level of loans, aggravating their crises (Dantas, Carvalho \& Pereira, 2018). Moreover, it is worth mentioning that, in credit unions, social capital, unlike traditional financial institutions, is redeemable; therefore, the cooperative can go out and redeem all its capital, which makes it volatile, and may even compromise indicators related to prudential regulation, such as the Basel index (Diniz \& Girão, 2019).

\section{Conclusions}

This article aimed, in a first effort, to analyze the relationship between conditional conservatism in Brazilian singular credit cooperatives that soften or not their results in the period between 2012 and 2018, since studies that relate the attributes of the quality of accounting information to these institutions are scarce and that applications in Brazilian financial institutions still lack greater results. 
To achieve the purpose of this research, the separation of these institutions was proposed into two groups according to Eckel's model (1981): credit unions smoothers, considering those cooperatives i who in the period $t$ softened their results (smoothers) and those that do not soften (non-smoothers). In sequence, the model of conditional conservatism of Ball and Shivakumar (2005) was applied, which considered the variation of leftovers for the period analyzed, using the years 2010 and 2011 for the outdated calculation. Thus, the sample of this study consisted of a total of 5,717 observations, 3,125 referring to credit unions that smooth their results (smoothers) and 2,592 to those that do not smooth (non-smoothers), whose regression was estimated by means of panel data with fixed effects, considered the respective tests.

Generally speaking, the results highlight a higher level of conservatism on the part of non-smoother credit cooperatives, demonstrating that by smoothing the remains of the cooperative, managers seek to be less conservative in advancing possible losses, reversing lower results in subsequent periods, which confirms the hypothesis proposed in this research. This fact minimizes possible agency conflicts, since, in the extreme, negative results signal an inefficiency of the entity in its processes of financial intermediation or in the management of the portfolio of credit operations, bringing greater instability to its cooperatives, resulting even in the reduction of the cooperative's share capital.

As seen, the present work sought a direct separation between two groups to analyze the level of conservatism in credit unions. In this respect, for future work, the adoption of a single panel is suggested, analyzing credit unions as a whole, considering, in addition, highlights related to the specific behavior of free admission cooperatives or segmentation among full, classical and capital and loan cooperatives, according to Resolution No. 4,434 (Bacen, 2015).

\section{References}

Arruda, A. G. S. (2014). Estruturas de Governança em Redes de Cooperativas de Crédito. Brasília: Confebras.

Arruda, M. P., Vieira, C. A., Paulo, E., \& Lucena, W. G. (2015). Análise do conservadorismo e persistência dos resultados contábeis das instituições financeiras brasileiras. Sociedade, Contabilidade e Gestão, 10 (2), 2335.

Ball, R., \& Shivakumar, L. (2005). Earnings quality in UK private firms: comparative loss recognition timeliness. Journal of Accounting and Economics, 39(1), 83-128.

Brazilian Central Bank [Bacen]. (1987). Circular n 1.273, de 29 de dezembro de 1987. Instituem, para adoção obrigatória a partir do Balanço de 30.06.88, o anexo Plano Contábil das Instituições do Sistema Financeiro Nacional - COSIF. from https://www.bcb.gov.br/pre/normativos/circ/1987/pdf/circ 1273 v1 o.pdf.

Brazilian Central Bank [Bacen]. (1999). Resolução n 2.682, de 21 de dezembro de 1999. Dispõe sobre critérios de classificação das operações de crédito e regras para constituição de provisão para créditos de liquidação duvidosa. Recovered from https://www.bcb.gov.br/pre/normativos/res/1999/pdf/res 2682 v2 L.pdf.

Brazilian Central Bank [Bacen]. (2015). Resolução no 4.434 de 5 de agosto de 2015. Dispõe sobre a constituição, a autorização para funcionamento, o funcionamento, as alterações estatutárias e o cancelamento de autorização para funcionamento das cooperativas de crédito e dá outras providências. Recovered from https://www.bcb.gov.br/pre/normativos/busca/downloadNormativo.asp?arquivo=/Lists/Normativo s/Attachments/48507/Res 4434 v1 O.pdf.

Brazilian Central Bank [Bacen]. (2018). Panorama do Sistema Nacional de Crédito Cooperativo. 2017. Recovered from

https://www.bcb.gov.br/content/estabilidadefinanceira/coopcredpanorama/panorama de cooperativ as2017.pdf. 
Brazilian Central Bank [Bacen]. (2019). Relação de Instituições em Funcionamento no País (transferência de arquivos). Recovered

from https://www.bcb.gov.br/estabilidadefinanceira/relacao instituicoes funcionamento.

Basu, S. (1997). The Conservatism Principle and the Asymmetric Timeliness of Earnings. Journal of Accounting and Economics, 24(1), 3-37.

Brazil. (2009). Lei Complementarn 130, de 17 de abril de 2009. Dispõe sobre o Sistema Nacional de Crédito Cooperativo e revoga dispositivos das Leis nos 4.595, de 31 de dezembro de 1964, e 5.764, de 16 de dezembro de 1971. Recovered from http://www.planalto.gov.br/ccivil 03/leis/lcp/Lcp130.htm.

Bressan, V. G. F., Souza, D. C. D., \& Bressan, A. A. (2017). Income smoothing: a study of the health sector's credit unions. Revista Brasileira de Gestão de Negócios, 19(66), 627-643.

Bressan, V. G. F., Bressan, A. A., \& da Silva Júnior, J. M. (2015). Evitar Divulgar Perdas: Foi Uma Estratégia Utilizada na Última Década pelas Cooperativas de Crédito Filiadas ao Sicredi?. Revista de Gestão e Organizações Cooperativas, 2(3), 27-42.

Bressan, V. G. F., Bressan, A. A., \& Silva Junior, J. M. da (2016). Gerenciamento de resultados em cooperativas no Brasil: Avaliando o Income Smoothing às filiadas do Sicredi. Advances in Scientific and Applied Accounting, 9(3), 283-300.

Bressan, V. G. F., Souza, D. C. D., \& Bressan, A. A. (2017). Income smoothing: a study of the health sector's credit unions. Revista Brasileira de Gestão de Negócios, 19(66), 627-643.

Carvalho, F. L., Diaz, M. D. M., Bialoskorski Neto, S. B., \& Kalatzis, A. E. G. (2015). Saída e insucesso das cooperativas de crédito no Brasil: uma análise do risco. Revista Contabilidade \& Finanças, 26 (67), 7084.

Carvalho, J. A., Pereira, J. V., \& Dantas, J. A. (2018). As instituições financeiras brasileiras usam a PCLD para gerenciamento de capital? Enfoque: Reflexão Contábil, 37 (2), 127-140.

Dechow, P. M. \& Schrand, C. M. (2004). Earnings quality. Charlottesville (Virginia): CFA Institute.

Diniz, M. M. \& Girão, L. F. de A. P. (2019, julho). Persistência das Sobras: Uma análise nas Cooperativas de Crédito singulares brasileiras. Anais do USP International Conference in Accounting, São Paulo, SP, Brasil, 19.

Diniz, M. M. (2020). Qualidade da Informação Contábil: Um estudo das Cooperativas de Crédito Brasileiras (Dissertação (Mestrado). Programa de Pós-Graduação em Ciências Contábeis, Universidade Federal da Paraíba, João Pessoa, PB, Brasil. Recovered from http://www.ccsa.ufpb.br/ppgcc/colecoes/dissertacoes.

Eckel, N. (1981). The Income Smoothing Hypothesis Revisited. Abacus, 17(1), 28-40.

Fávero, F., \& Belfiore, P. (2017). Manual de Análise de Dados: Estatística e Modelagem Multivariada com Excelß, SPSS $\AA_{\text {e Stata }}{ }^{\circledR}$. Rio de Janeiro: Elsevier.

Firnanti, F. (2019). The Influence of Dividend Policy and Income Tax on Income Smoothing. Accounting and Finance Review, 4(1), 15-20.

Gujarati, D. N., \& Porter, D. C. (2011). Econometria Básica. Porto Alegre: AMGH.

Hepworth, S. R. (1953). Smoothing Periodic Income. The Accounting Review, 28(1), 32-39.

Jansen, A., Maehler, A., \& Wegner, D. (2018). Governança cooperativa e o dilema da legitimidade: Um estudo de caso em uma cooperativa de crédito. Revista Iberoamericana de Estratégia, 17(3), 61-80.

John, K., De Masi, S., \& Paci, A. (2016). Corporate Governance in Banks. Corporate Governance: An International Review, 24(3), 303-321. 
Lambert, R. A. (1984). Income Smoothing as Rational Equilibrium Behavior. Accounting Review, 59 (4), 604-618.

Lara, J. M. G., Osma, B. G., \& Penalva, F. (2016). Accounting conservatism and firm investment efficiency. Journal of Accounting and Economics, 61 (1), 221-238.

Maia, S. C., Bressan, V. G. F., Lamounier, W. M., \& Braga, M. J. (2013). Gerenciamento de resultados em cooperativas de crédito no Brasil. Brazilian Business Review, 10(4), 96 - 116.

Martinez, A. L. (2001). "Gerenciamento” dos resultados contábeis: Estudo empirico das companbias abertas brasileiras (Tese (Doutorado). Faculdade de Economia, Administração e Contabilidade, Universidade de São Paulo, São Paulo, SP, Brasil. Recovered from http://www.teses.usp.br/teses/disponiveis/12/12136/tde14052002-110538/pt-br.php.

Martinez, A. L. (2006). Minimizando a variabilidade dos resultados contábeis: Estudo empírico do Income smoothing no Brasil. Revista Universo Contábil, 2(1), 9-25.

Martinez, A. L., \& Castro, M. A. R. (2011). The smoothing hypothesis, stock returns and risk in Brazil. BAR-Brazilian Administration Review, 8(1), 1-20.

Martinez, A. L. (2013). Earnings management in Brazil: um survey da literatura. Brazilian Business Review, $10(4), 1-31$.

Osma, B. G., Mora, A., \& Porcuna-Enguix, L. (2019). Prudential Supervisors' Independence and Income Smoothing in European Banks. Journal of Banking \& Finance, 102, 156-176.

Rezende, G. P. \& Nakao, S. H. (2012). Gerenciamento de resultados e a relação com o lucro tributável das empresas brasileiras de capital aberto. Revista Universo Contábil, 8 (1), 6-21.

Rixon, D., \& Lightstone, K. (2016). Impact of International Financial Reporting Standards on Canadian Credit Unions. International Journal of Business, Accounting, \& Finance, 10(1), 90-102.

Santos, W. P., Anjos, L. C., Rodrigues, R. N., \& Tavares, M. F. N. (2019). Análise da Influência do Cenário Econômico Interno e Externo na Prática de Income Smoothing em Bancos Brasileiros. Revista Evidenciação Contábil \& Finanças, 7(1), 78-93.

Watts, R. L. (2003). Conservatism in accounting part I: Explanations and implications. Accounting Horizons, 17(3), 207-221.

Zeghal, D., \& Lahmar, Z. (2018). The effect of culture on accounting conservatism during adoption of IFRS in the EU. International Journal of Accounting \& Information Management, 26(2), 311-330. 